\title{
THE PHYSICAL PROPERTIES OF THE LUNG IN CHRONIC OBSTRUCTIVE PULMONARY EMPHYSEMA ${ }^{1}$
}

\author{
By REUBEN M. CHERNIACK 2, 3 \\ (From the Departments of Environmental Medicine and of Medicine, The Johns Hopkins \\ University and Hospital, Baltimore, Md.)
}

(Submitted for publication September 12, 1955; accepted December 14, 1955)

The physical properties of the lung with which this paper is concerned, are the forces which are required to overcome the resistances in the respiratory system. These resistances are the elastic resistance of the lung to expansion, and the various viscous resistances involved in the movement of air into and out of the lungs with associated movement of lung tissue.

Simultaneous recording of air flow and intrathoracic pressure enables assessment of the forces required to overcome these resistances. The elastic resistance of the lungs is expressed as the compliance (volume change in liters per centimeter of water-pressure change from end expiration to end inspiration), while the viscous resistance can be differentiated into that proportional to the velocity of air flow (streamline resistance in the airways and movement of lung tissue) and that proportional to the square of the velocity of air flow (turbulent resistance in the airways) (1).

This paper reports the disturbances in the physical properties of the lungs in patients with chronic pulmonary emphysema and in a group of emphysematous patients who had associated right heart failure.

\section{SUBJECTS AND METHODS}

Subjects consisted of seven normal individuals (Table I) and 18 patients with chronic obstructive airway disease of mild to moderate degree, six of whom had developed right heart failure (Tables II and III). All gave

1 This study was aided by a contract between the Office of Naval Research, Department of the Navy, and The Johns Hopkins University (NR 112-101) and was also supported by funds provided under Contract AF 18 (600)435 with the USAF School of Aviation Medicine, Randolph Field, Texas.

2 Postdoctoral Fellow of The Life Insurance Medical Research Fund.

3 Present address : Faculty of Medicine, The University of Manitoba, Winnipeg, Canada. a history of dyspnea on exertion for two to twenty years. The diagnosis was based on the evidence of disturbances of pulmonary function (Tables II and III) and the clinical findings of an increased antero-posterior diameter of the chest, depressed diaphragms with limitation of movement, and signs of bronchial obstruction on physical examination. Although not shown in the tables, the shape of the expiratory vital capacity tracing was characteristic of obstruction to expiratory outflow in all cases. Right heart failure was diagnosed on the basis of electrocardiographic findings of right ventricular hypertrophy and the clinical findings of venous hypertension, enlarged liver and peripheral edema.

Lung volumes and maximal breathing capacities were predicted and measured by methods described by Baldwin, Cournand, and Richards (2). Dead space/tidal air ratios, venous admixture and maximal diffusing capacities were determined by methods described by Riley and his associates $(3,4)$.

Esophageal pressure was used to estimate intrathoracic pressure (5-7) in spite of known differences between esophageal and intrapleural pressures (8), because values for compliance and resistance determined with esophageal pressures approximated those using intrapleural pressure sufficiently in the tidal volume range for evaluation of the physiologic abnormalities under consideration (9). The esophageal pressure was measured by means of an air filled, thin-walled rubber balloon which has been previously described (8). All measurements were made within the lower third of the esophagus.

The rate of air flow into and out of the lungs was measured by means of a pneumotachometer containing a 325 mesh stainless steel screen which offered a resistance of $0.07 \mathrm{~mm} . \mathrm{H}_{2} \mathrm{O}$ per liter per minute of air flow. The pressure drop across the pneumotachometer screen was measured by means of a Statham differential pressure strain gauge transducer (maximum range \pm 0.05 p.s.i.). The volume of air breathed was determined by measuring the area under the pneumotachograph with a planimeter.

Subjects breathed through a mouth piece connected to the pneumotachometer by a short length of rubber tubing, one inch in diameter. A solenoid-operated slide valve was introduced between the mouth of the subject and the pneumotachometer in order to interrupt the flow of air at the mouth at varying times during the respiratory cycle. A side tap in the tubing between the subject's mouth permitted the esophageal-mouth differential pressure to be measured by means of a Statham differ- 
PHYSICAL PROPERTIES OF THE LUNG IN EMPHYSEMA

TABLE I

Physical properties of the lung in normal subjects

\begin{tabular}{|c|c|c|c|c|c|c|c|c|c|c|c|}
\hline \multirow[b]{2}{*}{ Subject } & \multirow[b]{2}{*}{$\begin{array}{c}\text { Age } \\
\text { (yrs.) }\end{array}$} & \multirow[b]{2}{*}{ Sex } & \multirow[b]{2}{*}{$\underset{(\mathrm{cm} .)}{\text { Height }}$} & \multirow[b]{2}{*}{$\underset{\text { (liters) }}{\mathrm{VC}}$} & \multicolumn{2}{|c|}{$\begin{array}{l}\text { Compliance } \\
\left(\mathrm{l} . / \mathrm{cm} . \mathrm{H}_{2} \mathrm{O}\right)\end{array}$} & \multirow[b]{2}{*}{$\begin{array}{c}\text { Coeff. of } \\
\text { linear } \\
\text { resistance }\end{array}$} & \multirow[b]{2}{*}{$\begin{array}{l}\text { Coeff. of } \\
\text { turbulent } \\
\text { resistance }\end{array}$} & \multicolumn{3}{|c|}{ Work of breathing } \\
\hline & & & & & $\begin{array}{l}\text { Func- } \\
\text { tional }\end{array}$ & Static & & & Elastic & $\begin{array}{l}\text { Viscous } \\
\text { (gm. m./ } \\
\text { liter vent.) }\end{array}$ & Total \\
\hline $\begin{array}{l}\text { G. B. } \\
\text { R. C. } \\
\text { H. D. } \\
\text { J. F. } \\
\text { J. K. } \\
\text { V. N. } \\
\text { R. R. }\end{array}$ & $\begin{array}{l}32 \\
30 \\
34 \\
22 \\
25 \\
24 \\
42\end{array}$ & $\begin{array}{l}\mathbf{M} \\
\mathbf{M} \\
\mathbf{M} \\
\mathbf{M} \\
\mathbf{F} \\
\mathbf{F} \\
\mathbf{M}\end{array}$ & $\begin{array}{l}178 \\
179 \\
174 \\
180 \\
170 \\
163 \\
177\end{array}$ & $\begin{array}{l}\mathbf{5 . 5 6} \\
5.92 \\
4.86 \\
5.20 \\
3.82 \\
3.64 \\
5.24\end{array}$ & $\begin{array}{l}.212 \\
.245 \\
.295 \\
.226 \\
.142 \\
.120 \\
.140\end{array}$ & $\begin{array}{l}.202 \\
.248 \\
.333 \\
.222 \\
.133 \\
.121 \\
.148\end{array}$ & $\begin{array}{l}1.7 \\
1.2 \\
1.5 \\
1.6 \\
1.8 \\
3.0 \\
1.2\end{array}$ & $\begin{array}{l}0.13 \\
0.16 \\
0.38 \\
0.26 \\
0.24 \\
0.12 \\
0.30\end{array}$ & $\begin{array}{l}14.0 \\
14.5 \\
28.2 \\
18.5 \\
20.0 \\
24.0 \\
17.5\end{array}$ & $\begin{array}{r}21.4 \\
4.9 \\
8.2 \\
20.0 \\
17.9 \\
15.2 \\
19.0\end{array}$ & $\begin{array}{l}23.0 \\
16.9 \\
32.0 \\
24.9 \\
29.5 \\
31.5 \\
23.0\end{array}$ \\
\hline Mean & & & & & .197 & .201 & 1.71 & 0.23 & 19.4 & 15.2 & 25.8 \\
\hline
\end{tabular}

ential pressure strain gauge transducer (maximum range \pm 0.6 p.s.i.).

Tracings of the air flow and esophageal-mouth differential pressure were recorded simultaneously by means of a Sanborn amplifying recorder.

All subjects were studied in the sitting position. The subjects with pulmonary emphysema were studied prior to, and 10 to 15 minutes after, the inhalation of nebulized bronchodilator (IsuprelB). The pneumotachometer was calibrated using rotameters and the pressure gauges were calibrated using a water manometer after each study.

Simultaneous measurements of the pressure and volume changes from end-expiration, determined at intervals of 0.2 seconds, were plotted one against the other during a complete breathing cycle. The area of the loop which was obtained represented the mechanical work done on the lungs in order to overcome viscous resistance, and was expressed in gram meters.
The pressure required to overcome the elastic resistance of the lungs during the breathing cycle was determined by joining the points at end expiration and end inspiration. The elastic properties of the lungs were expressed as the volume change per centimeter of water pressure change or the compliance. The mechanical work required to overcome elastic resistance was determined by the method described by McIlroy, Marshall, and Christie (10) and Comroe, Forster, DuBois, Briscoe, and Carlsen (11), and expressed in gram meters.

It may be noted that there is not complete agreement regarding the method of measurement of the elastic work done on the lung. Otis (12) has described another method but because esophageal pressure does not yield absolute intrathoracic pressure (8), it was not possible to estimate elastic work by this method.

In the normal subjects, the expiratory portion of the pressure-volume loop usually fell within the elastic work

TABLE II

Estimation of ventilatory function in patients with pulmonary emphysema

\begin{tabular}{|c|c|c|c|c|c|c|c|c|c|c|c|}
\hline \multirow[b]{3}{*}{ Group } & \multirow[b]{3}{*}{ Subject } & \multirow{3}{*}{$\begin{array}{c}\text { Age } \\
\text { (yrs.) }\end{array}$} & \multirow[b]{3}{*}{$\operatorname{Sex}$} & \multirow{3}{*}{$\underset{(\mathrm{cm} .)}{\mathrm{Ht}}$} & \multirow{3}{*}{$\begin{array}{c}\text { History of } \\
\text { dyspnea } \\
\text { (years) }\end{array}$} & \multicolumn{3}{|c|}{ Vital capacity (liters) } & \multicolumn{3}{|c|}{$\underset{(l . / m i n .)}{\text { Maximum breathing capacity }}$} \\
\hline & & & & & & \multirow{2}{*}{$\begin{array}{l}\text { Pre- } \\
\text { dicted }\end{array}$} & Before & After & \multirow{2}{*}{$\begin{array}{l}\text { Pre- } \\
\text { dicted }\end{array}$} & Before & After \\
\hline & & & & & & & Broncho & latation & & \multicolumn{2}{|c|}{ Bronchodilatation } \\
\hline $\mathbf{I}$ & $\begin{array}{l}\text { E. B. } \\
\text { G. B. } \\
\text { S. F. } \\
\text { W. H. } \\
\text { N. J. } \\
\text { H. L. } \\
\text { A. P. } \\
\text { F. S. } \\
\text { W. S. } \\
\text { C. T. } \\
\text { B. W. } \\
\text { C. W. }\end{array}$ & $\begin{array}{l}48 \\
46 \\
54 \\
60 \\
33 \\
53 \\
52 \\
46 \\
67 \\
62 \\
52 \\
33\end{array}$ & $\begin{array}{l}\mathbf{M} \\
\mathbf{M} \\
\mathbf{M} \\
\mathbf{M} \\
\mathbf{F} \\
\mathbf{M} \\
\mathbf{M} \\
\mathbf{M} \\
\mathbf{M} \\
\mathbf{M} \\
\mathbf{M} \\
\mathbf{F}\end{array}$ & $\begin{array}{l}189 \\
174 \\
178 \\
168 \\
160 \\
161 \\
171 \\
173 \\
175 \\
174 \\
172 \\
145\end{array}$ & $\begin{array}{r}6 \\
2 \\
2 \\
6 \\
10 \\
3 \\
6 \\
15 \\
20 \\
3 \\
3 \\
5\end{array}$ & $\begin{array}{l}4.00 \\
3.90 \\
3.90 \\
3.42 \\
2.90 \\
3.34 \\
3.95 \\
3.83 \\
3.50 \\
3.60 \\
3.70 \\
2.45\end{array}$ & $\begin{array}{l}3.27 \\
2.63 \\
2.84 \\
1.78 \\
1.74 \\
1.80 \\
4.17 \\
3.47 \\
2.57 \\
2.81 \\
2.55 \\
2.60\end{array}$ & $\begin{array}{l}3.43 \\
2.79 \\
2.97 \\
2.14 \\
2.05 \\
2.25 \\
4.17 \\
4.33 \\
2.57 \\
3.11 \\
3.06 \\
3.10\end{array}$ & $\begin{array}{r}111 \\
110 \\
104 \\
91 \\
89 \\
92 \\
100 \\
98 \\
90 \\
92 \\
100 \\
75\end{array}$ & $\begin{array}{l}45 \\
32 \\
80 \\
38 \\
25 \\
22 \\
68 \\
45 \\
32 \\
38 \\
45 \\
26\end{array}$ & $\begin{array}{l}56 \\
37 \\
86 \\
40 \\
34 \\
28 \\
79 \\
54 \\
43 \\
57 \\
51 \\
33\end{array}$ \\
\hline II & $\begin{array}{l}\text { F. B. } \\
\text { W. B. } \\
\text { E. H. } \\
\text { J. M. } \\
\text { L. S. } \\
\text { E. W. }\end{array}$ & $\begin{array}{l}64 \\
58 \\
42 \\
42 \\
45 \\
54\end{array}$ & $\begin{array}{l}\mathbf{F} \\
\mathbf{M} \\
\mathbf{M} \\
\mathbf{M} \\
\mathbf{F} \\
\mathbf{F}\end{array}$ & $\begin{array}{l}153 \\
165 \\
160 \\
173 \\
150 \\
151\end{array}$ & $\begin{array}{l}15 \\
20 \\
13 \\
20 \\
10 \\
20\end{array}$ & $\begin{array}{l}2.25 \\
3.32 \\
3.60 \\
3.90 \\
2.40 \\
2.28\end{array}$ & $\begin{array}{l}1.19 \\
2.13 \\
2.66 \\
2.95 \\
0.83 \\
1.28\end{array}$ & $\begin{array}{l}1.87 \\
2.62 \\
3.54 \\
3.40 \\
1.28 \\
1.73\end{array}$ & $\begin{array}{r}69 \\
89 \\
100 \\
112 \\
70 \\
79\end{array}$ & $\begin{array}{l}11 \\
59 \\
40 \\
34 \\
17 \\
11\end{array}$ & $\begin{array}{l}20 \\
64 \\
51 \\
37 \\
25 \\
23\end{array}$ \\
\hline
\end{tabular}


TABLE III

Estimation of distribution and diffusion in patients with pulmonary emphysema

\begin{tabular}{|c|c|c|c|c|c|c|c|c|}
\hline \multirow[b]{2}{*}{ Group } & \multirow[b]{2}{*}{ Subject } & \multicolumn{2}{|c|}{ Arterial } & \multirow{2}{*}{ R.V. ${ }_{\text {X100 }}^{(1)}$ T.V. } & \multirow{2}{*}{$\underset{\mathrm{X} / \mathrm{(2)}}{\mathrm{VDT}}$} & \multirow{2}{*}{$\underset{\text { X100 }}{\stackrel{(3)}{\text { QेvàT }}}$} & \multicolumn{2}{|c|}{ 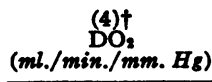 } \\
\hline & & $\mathrm{Pco}_{2}$ & $\mathrm{Po}_{2}$ & & & & Pred. & Obs. \\
\hline I & $\begin{array}{l}\text { E. B. } \\
\text { G. B. } \\
\text { S. F. } \\
\text { W. H. } \\
\text { N. J. } \\
\text { H. L. } \\
\text { A. P. }\end{array}$ & $\begin{array}{l}37 \\
46 \\
38 \\
46 \\
43 \\
52 \\
-\end{array}$ & $\begin{array}{l}61 \\
78 \\
80 \\
83 \\
88 \\
57 \\
\end{array}$ & $\begin{array}{l}52 \\
64 \\
44 \\
- \\
- \\
-\end{array}$ & $\begin{array}{l}46 \\
48 \\
22 \\
51 \\
41 \\
44 \\
-\end{array}$ & $\begin{array}{r}13 \\
4 \\
9 \\
4 \\
12 \\
18 \\
\end{array}$ & $\begin{array}{l}58 \\
51 \\
48 \\
39 \\
45 \\
37 \\
\end{array}$ & $\begin{array}{l}13 \\
10 \\
43 \\
19 \\
13 \\
22 \\
\end{array}$ \\
\hline & $\begin{array}{l}\mathbf{F} . \mathbf{S} . \\
\mathbf{W} . \mathbf{S} . \\
\mathbf{C} . \mathbf{T} . \\
\text { B. W. } \\
\text { C. W. }\end{array}$ & $\begin{array}{l}40 \\
38 \\
40 \\
42 \\
38\end{array}$ & $\begin{array}{l}80 \\
75 \\
85 \\
59 \\
86\end{array}$ & $\begin{array}{l}\frac{58}{-} \\
-\end{array}$ & $\begin{array}{l}49 \\
42 \\
46 \\
49 \\
\end{array}$ & $\begin{array}{r}8 \\
7 \\
7 \\
20 \\
\end{array}$ & $\begin{array}{l}49 \\
40 \\
41 \\
44 \\
-\end{array}$ & $\begin{array}{l}25 \\
31 \\
31 \\
18 \\
-\end{array}$ \\
\hline II & $\begin{array}{l}\text { F. B. } \\
\text { W. B. } \\
\text { E. H. } \\
\text { J. M. } \\
\text { L. S. } \\
\text { E. W. }\end{array}$ & $\begin{array}{r}70 \\
54 \\
60 \\
58 \\
54 \\
60\end{array}$ & $\begin{array}{l}40 \\
78 \\
46 \\
57 \\
70 \\
49\end{array}$ & $\begin{array}{l}\overline{55} \\
- \\
-\end{array}$ & $\begin{array}{l}58 \\
51 \\
41 \\
50 \\
50 \\
65\end{array}$ & $\begin{array}{r}17 \\
6 \\
6 \\
20 \\
13 \\
30\end{array}$ & $\begin{array}{l}20 \\
37 \\
48 \\
51 \\
27 \\
23\end{array}$ & $\begin{array}{c}6^{*} \\
18 \\
23 \\
20 \\
10^{*} \\
9\end{array}$ \\
\hline
\end{tabular}

(1) Ratio of residual volume to total lung volume.

(2) Ratio of dead space to tidal volume.

(3) Ratio of venous admixture to total blood flow.

(4) Maximal diffusing capacity for oxygen.

Group I-patients with emphysema.

Group II-patients with emphysema and heart failure.

* Studied at rest.

† Data obtained from Shepard and his associates (reference 22).

area during quiet breathing, indicating that expiratory viscous resistance was overcome by stored elastic energy. Any portion of the pressure-volume loop falling outside the elastic work area represented the additional active work required for expiration. The total work done on the lungs was calculated by adding the elastic work, the inspiratory viscous work and additional expiratory viscous work. The work per liter of ventilation was obtained by dividing the work per respiration by the volume of breath in liters.

The pressure required to overcome viscous resistance was determined from the pressure-volume loop or by interrupting the flow of air at the mouth with the solenoid interrupter. In the former case this was done

TABLE IV

Physical properties of the lung in patients with pulmonary emphysema

\begin{tabular}{|c|c|c|c|c|c|c|c|}
\hline \multirow[b]{4}{*}{ Subject } & \multicolumn{3}{|c|}{$\begin{array}{l}\text { Compliance } \\
(l . / \mathrm{cm} . H \Omega)\end{array}$} & \multirow{2}{*}{\multicolumn{2}{|c|}{$\begin{array}{l}\text { Coeff. of linear } \\
\text { resistance }\end{array}$}} & \multirow{2}{*}{\multicolumn{2}{|c|}{$\begin{array}{c}\text { Coeff. of turbulent } \\
\text { resistance }\end{array}$}} \\
\hline & \multicolumn{2}{|c|}{ Functional } & \multirow[b]{3}{*}{ Static } & & & & \\
\hline & Before & After & & Before & After & Before & After \\
\hline & \multicolumn{2}{|c|}{$\overline{\text { Bronchodilatation }}$} & & \multicolumn{2}{|c|}{$\overline{\text { Bronchodilatation }}$} & \multicolumn{2}{|c|}{ Bronchodilatation } \\
\hline $\begin{array}{l}\text { E. B. } \\
\text { G. B. } \\
\text { S. F. } \\
\text { W. H. } \\
\text { N. J. } \\
\text { H. L. } \\
\text { A. P. } \\
\text { F. S. } \\
\text { W. S. } \\
\text { C. T. } \\
\text { B. W. } \\
\text { C. W. }\end{array}$ & $\begin{array}{l}0.311 \\
0.210 \\
0.155 \\
0.303 \\
0.181 \\
0.088 \\
0.210 \\
0.214 \\
0.120 \\
0.200 \\
0.250 \\
0.140\end{array}$ & $\begin{array}{l}0.354 \\
0.280 \\
0.176 \\
0.360 \\
0.206 \\
0.211 \\
0.242 \\
0.246 \\
0.155 \\
0.223 \\
0.325 \\
0.312\end{array}$ & $\begin{array}{l}0.444 \\
0.358 \\
0.250 \\
0.450 \\
0.530 \\
0.240 \\
0.277 \\
0.480 \\
0.212 \\
0.333 \\
0.600 \\
0.329\end{array}$ & $\begin{array}{r}3.0 \\
2.4 \\
3.3 \\
2.8 \\
2.2 \\
3.8 \\
5.0 \\
2.5 \\
10.8 \\
2.1 \\
3.3 \\
3.9\end{array}$ & $\begin{array}{l}2.5 \\
2.2 \\
2.3 \\
2.5 \\
2.0 \\
3.1 \\
3.1 \\
1.3 \\
5.0 \\
0.9 \\
2.4 \\
1.9\end{array}$ & $\begin{array}{l}1.4 \\
0.4 \\
0.1 \\
1.0 \\
0.3 \\
0.4 \\
2.4 \\
1.4 \\
1.1 \\
1.7 \\
1.7 \\
0.5\end{array}$ & $\begin{array}{l}0.8 \\
0.3 \\
0.1 \\
0.8 \\
0.2 \\
0.2 \\
0.3 \\
1.1 \\
0.2 \\
0.8 \\
0.3 \\
0.1\end{array}$ \\
\hline Mean & 0.198 & 0.257 & 0.379 & 3.76 & 2.43 & 1.03 & 0.43 \\
\hline
\end{tabular}


TABLE V

Physical properties of the lung in patients with pulmonary emphysema and right heart failure

\begin{tabular}{|c|c|c|c|c|c|c|c|}
\hline \multirow[b]{4}{*}{ Subject } & \multicolumn{3}{|c|}{$\begin{array}{l}\text { Compliance } \\
\left(l_{1} / \mathrm{cm} . \mathrm{H}, 0\right)\end{array}$} & \multirow{2}{*}{\multicolumn{2}{|c|}{$\begin{array}{l}\text { Coeff. of linear } \\
\text { resistance }\end{array}$}} & \multirow{2}{*}{\multicolumn{2}{|c|}{$\begin{array}{c}\text { Coeff. of turbulen } \\
\text { resistance }\end{array}$}} \\
\hline & \multicolumn{2}{|c|}{ Functional } & & & & & \\
\hline & Before & After & \multirow[b]{2}{*}{ Static } & Before & After & Before & After \\
\hline & \multicolumn{2}{|c|}{ Bronchodilatation } & & \multicolumn{2}{|c|}{ Bronchodilatation } & \multicolumn{2}{|c|}{ Bronchodilatation } \\
\hline $\begin{array}{l}\text { F. B. } \\
\text { W. B. } \\
\text { E. H. } \\
\text { J. M. } \\
\text { L. S. } \\
\text { E. W. }\end{array}$ & $\begin{array}{l}0.082 \\
0.074 \\
0.035 \\
0.033 \\
0.030 \\
0.044\end{array}$ & $\begin{array}{l}0.102 \\
0.099 \\
0.040 \\
0.063 \\
0.042 \\
0.056\end{array}$ & $\begin{array}{l}0.183 \\
0.185 \\
0.103 \\
0.190 \\
0.072 \\
0.105\end{array}$ & $\begin{array}{r}8.0 \\
1.5 \\
6.6 \\
10.7 \\
6.0 \\
3.9\end{array}$ & $\begin{array}{l}4.1 \\
1.2 \\
6.0 \\
5.4 \\
1.2 \\
2.8\end{array}$ & $\begin{array}{l}1.1 \\
1.7 \\
1.5 \\
9.8 \\
1.8 \\
1.4\end{array}$ & $\begin{array}{l}0.4 \\
1.0 \\
0.8 \\
6.0 \\
0.8 \\
0.3\end{array}$ \\
\hline Mean & 0.050 & 0.067 & 0.140 & 6.11 & 3.45 & 2.88 & 1.5 \\
\hline
\end{tabular}

by subtracting the pressure required to overcome elastic resistance from the intrathoracic pressure for any particular instant in the respiratory cycle. In the latter case the difference between the intrathoracic pressure, measured the instant prior to interruption, and the pressure measured during interruption, yielded the pressure required to overcome air and tissue viscous resistance. These pressures were plotted against simultaneously recorded rates of air flow. Values for the coefficients of linear and turbulent resistance to air flow during inspiration were approximated from these pressure-flow curves by determining the first and second derivatives as described by Fry, Ebert, Stead, and Brown (13).

\section{RESULTS}

The physical properties of the lungs found in the normal individuals are presented in Table $I$. The results obtained before and after bronchodilatation in patients with pulmonary emphysema are presented in Table IV, while those obtained in the emphysematous patients who had developed right heart failure are presented in Table V.

\section{A. Compliance}

In patients with pulmonary emphysema it was noted that the compliance of the lungs varied with the rate at which the subject was breathing. The change in compliance during slow breathing could not be attributed to changes in resting level of the lung since there was no change in lung volume as determined on a spirometer tracing, when inspiration was slowed. In order to determine the effect of respiratory rate, the compliance of the lungs was determined during inspirations of approximately equal volume but varying in duration.

The compliances found with the different dura- tions of inspiration in a representative subject from each of the three groups are shown in Figure 1. Each point represents the average of three to six determinations. It can be seen that in the patients with pulmonary emphysema the compliance increased considerably when inspiration was slowed, until a plateau was reached after which it remained fairly constant. The compliance obtained while breathing at the resting respiratory rate is hereafter referred to as the functional com-

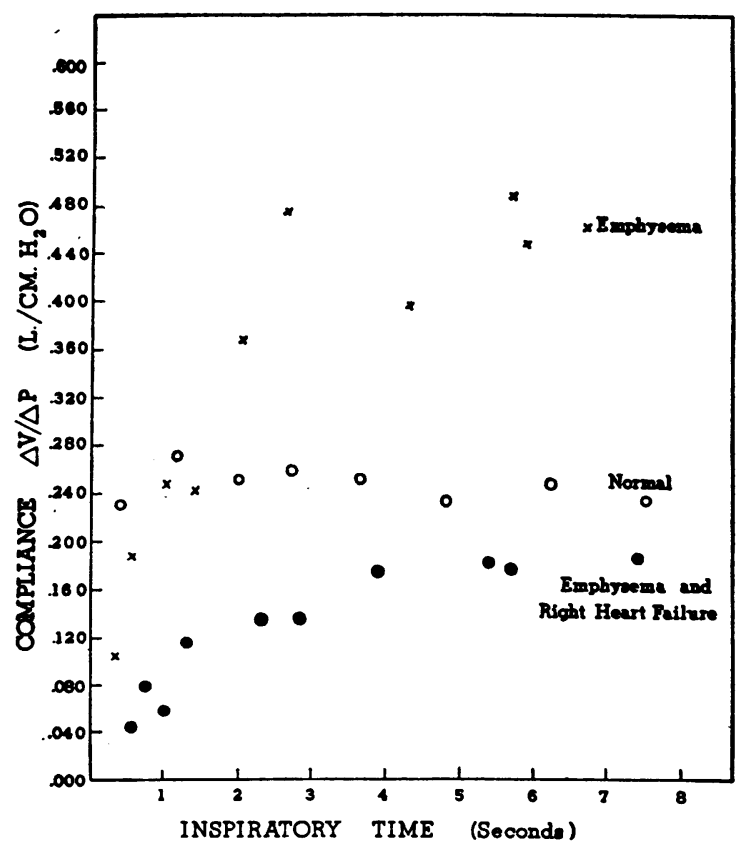

Fig. 1. The Effect of Varying Duration of InSPIRATION ON Compliance of the Lung in a Normal Subject, a Subject with Emphysema, and a Subject with Emphysema and Right Heart Failure 


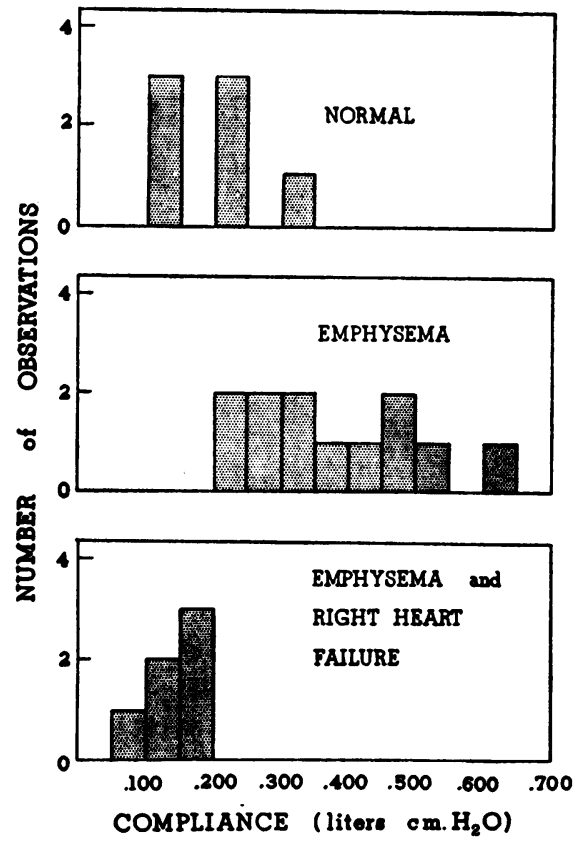

Fig. 2. Frequency Distribution of Static ComPLIANCE in Normals, EMPhySEMa, aNd EMPHYSEMa with Right Heart FaILURe

pliance, while the value for compliance at the plateau, during the slow inspirations, is referred to as the static compliance of the lungs. The functional compliance was frequently lower than the normal in the abnormal subjects. In normal subjects, functional and static compliances were approximately the same (Table I), whereas in the abnormal subjects the static compliance was far greater than the functional compliance (Tables IV and V).

Figure 2 presents the frequency distribution of the static compliance of the lungs found in the normal subjects, patients with pulmonary emphysema and patients with emphysema who had developed heart failure. From this figure and Tables IV and V, it can be seen that in patients wih pulmonary emphysema the static compliance of the lungs was generally greater than that of the normal, while in those patients with associated heart failure the compliance of the lungs was low.

\section{B. Viscous resistance}

The coefficients of linear and turbulent resistance found in the normals are presented in Table
I, while those found in the patients with pulmonary emphysema are presented in Tables IV and $V$. The mean coefficient of linear resistance during spontaneous respiration was lowest in the normal subjects, and highest in those patients who had developed right heart failure, being 1.71 in the normals, 3.76 in the group with emphysema, and 6.11 in the group which had developed heart failure. Similar results were found for the mean coefficients of turbulent resistance, being 0.23 in the normal subjects, 1.03 in the emphysematous patients and 2.88 in the patients in whom heart failure was also present.

\section{Work of breathing}

Frequency distributions of the work of breathing at the normal resting respiratory rate in the normal subjects, patients with pulmonary emphysema and patients with emphysema who had developed right heart failure are presented in Figure 3. It can be seen that the work required to overcome elastic resistance was slightly higher than the normal in the emphysematous subjects and much higher in the patients with associated right heart failure. The total work of breathing was far greater than the normal in the emphysematous patients and still greater in the group who had developed right heart failure, this increase being particularly due to that required to overcome viscous resistance. In the abnormal subjects the expiratory portion of the pressure-volume loop frequently fell outside the elastic work area indicating active work during expiration.

\section{Effect of nebulized bronchodilator}

The functional compliance noted during quiet breathing after the administration of bronchodilator was frequently greater than that observed before bronchodilator (Tables IV and V). Although not shown in the tables, the inhalation of bronchodilator did not alter the static compliance since a plateau was reached at the same level that was obtained prior to the administration of bronchodilator.

An example of the effect of nebulized bronchodilator in a patient with emphysema and right heart failure is illustrated in Figures 4 and 5 . It can be seen that inhalation of the bronchodilator 

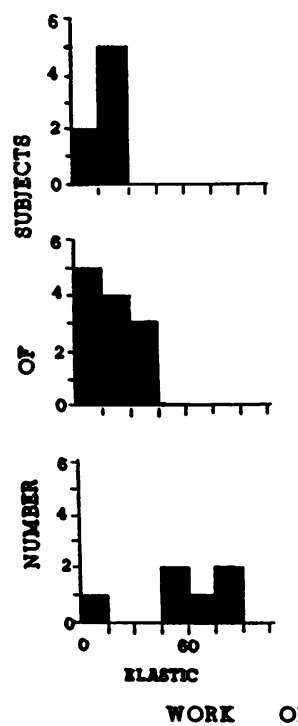
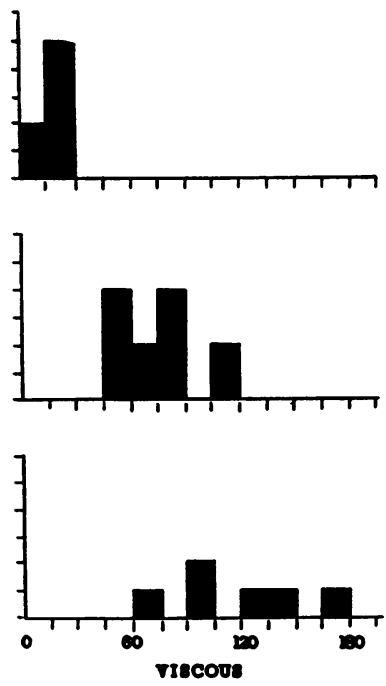

or
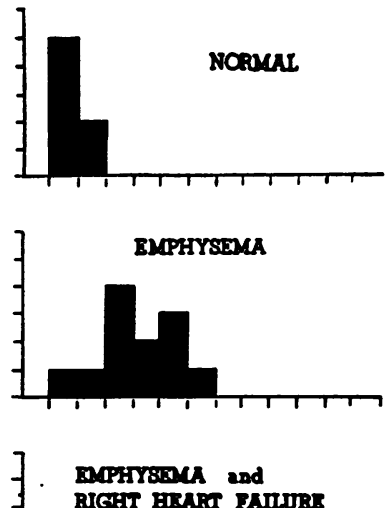

RIGHT BTNRT TANUR

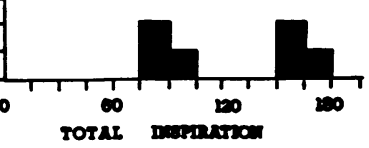

or verrmanom)

Fig. 3. Frequency Distribution of Work Required to Overcome Elastic Resistance, Viscous Resistance and Total Work of Breathing in Normals, Emphysema, and Emphysema with Right Heart FaIlure

resulted in a considerable reduction in elastic and viscous resistance and work required to overcome these resistances.

The effect of nebulized bronchodilator on the viscous resistance in the abnormal subjects is presented in Tables IV and V. In the emphysematous subjects there was a 35 per cent decrease in the mean co-efficient of linear resistance, and a 58 per cent decrease in the mean co-efficient of turbulent resistance. In the emphysematous subjects who had developed right heart failure, the mean co-efficient of linear resistance diminished by 43 per cent, while the mean co-efficient of turbulent resistance diminished 48 per cent.

The effect of nebulized bronchodilator on the work of breathing in the abnormal subjects is presented in Tables VI and VII. In the emphysematous patients, nebulized bronchodilator resulted in a mean reduction in total work of 17 per cent, the elastic work being reduced by 24 per cent, while the viscous work was reduced by 26 per cent (Table VI). In the patients who had

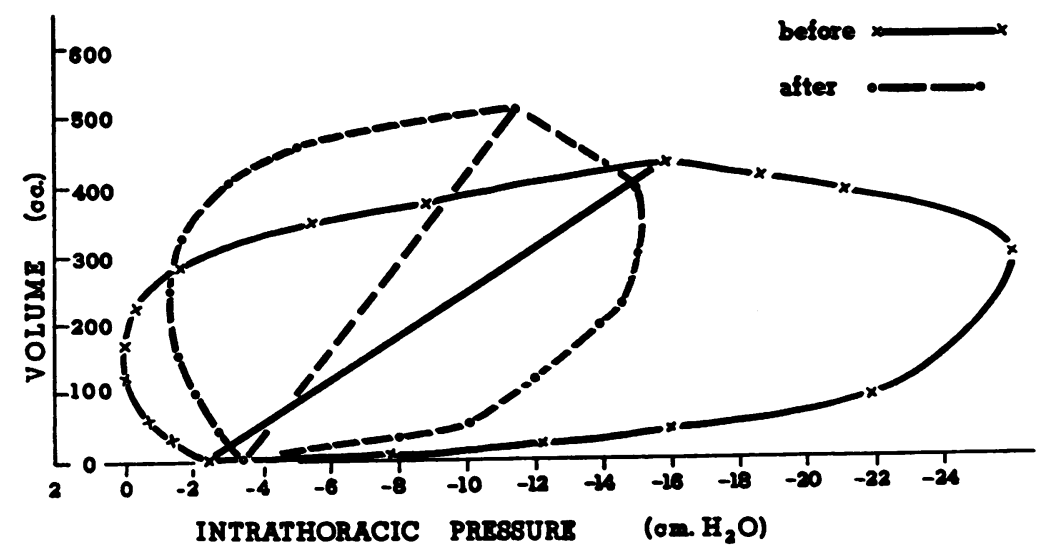

Fig. 4. The Effect of Nebulized Bronchodilator on the PressureVolume Loop in a Subject with Emphysema and Right Heart FAILURE 


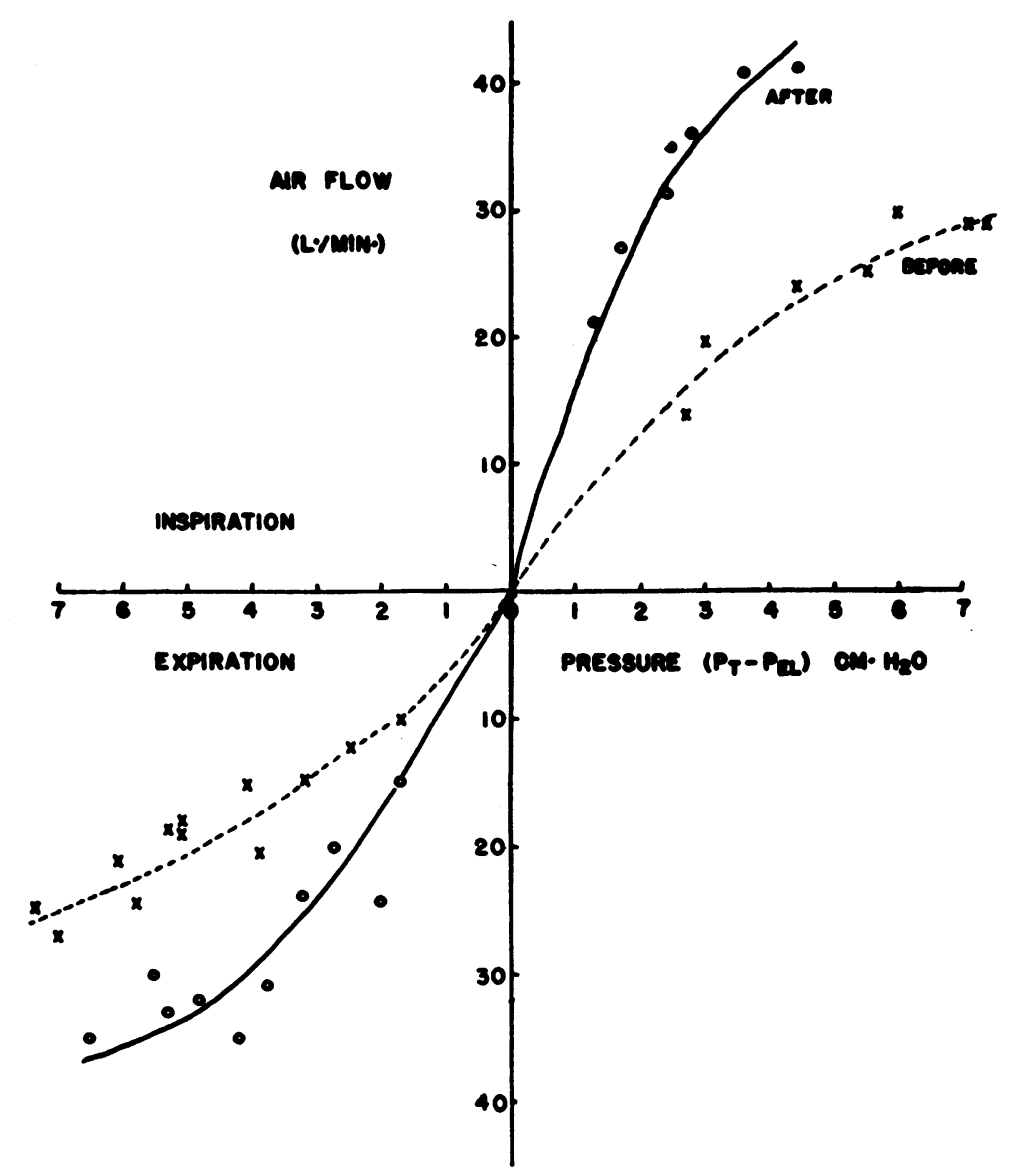

Fig. 5. The Effect of Nebulized Bronchodilator on PressureFlow Relatronships in a SUbject with Emphysema and Right HEART FAILURE

TABLE VI

The effect of nebulized bronchodilator on the work of breathing in patients with emphysema

\begin{tabular}{|c|c|c|c|c|c|c|}
\hline \multirow[b]{3}{*}{ Subject } & \multicolumn{6}{|c|}{$\begin{array}{l}\text { Work of breathing } \\
\text { (gm. m./liter ventilation) }\end{array}$} \\
\hline & \multicolumn{2}{|c|}{ Elastic } & \multicolumn{2}{|c|}{ Viscous } & \multicolumn{2}{|c|}{ Total } \\
\hline & Before & After & Before & After & Before & After \\
\hline $\begin{array}{l}\text { E. B. } \\
\text { G. B. } \\
\text { S. F. } \\
\text { W. H. } \\
\text { N. J. } \\
\text { H. L. } \\
\text { A. P. } \\
\text { F. S. } \\
\text { W. S. } \\
\text { C. T. } \\
\text { B. W. } \\
\text { C. W. }\end{array}$ & $\begin{array}{r}14.0 \\
13.5 \\
37.0 \\
15.1 \\
19.6 \\
29.0 \\
21.0 \\
9.0 \\
25.0 \\
36.0 \\
15.0 \\
31.0\end{array}$ & $\begin{array}{r}12.6 \\
10.5 \\
30.0 \\
13.5 \\
19.0 \\
13.0 \\
16.0 \\
8.0 \\
17.0 \\
29.0 \\
11.5 \\
22.0\end{array}$ & $\begin{array}{r}54.0 \\
84.5 \\
46.0 \\
59.5 \\
71.6 \\
109.0 \\
80.2 \\
45.7 \\
115.0 \\
88.0 \\
71.0 \\
88.0\end{array}$ & $\begin{array}{l}38.6 \\
63.6 \\
28.0 \\
46.4 \\
57.0 \\
75.5 \\
57.9 \\
26.6 \\
93.5 \\
58.6 \\
61.4 \\
65.0\end{array}$ & $\begin{array}{r}52.5 \\
59.8 \\
75.0 \\
60.6 \\
52.0 \\
80.8 \\
54.0 \\
26.2 \\
102.0 \\
87.6 \\
43.2 \\
66.3\end{array}$ & $\begin{array}{l}42.6 \\
53.8 \\
40.0 \\
46.5 \\
51.9 \\
49.3 \\
41.5 \\
23.4 \\
83.0 \\
50.9 \\
37.3 \\
25.1\end{array}$ \\
\hline Mean & 22.2 & 16.8 & 76.0 & 56.0 & 55.0 & 45.4 \\
\hline
\end{tabular}

developed right heart failure total work was re. duced by 28 per cent, elastic work being reduced by 28 per cent and the viscous work by 20 per cent (Table VII).

\section{DISCUSSION}

Normal or low compliance, i.e., increased rigidity of the lungs was found in the patients with pulmonary emphysema, particularly in those who had developed heart failure, while breathing at their normal resting respiratory rate. However, it was also found that the compliance of the lungs varied with the respiratory rate, becoming much higher when inspiration was particularly slow. This change is consistent with the findings of Otis and McKerrow (14) in a lung model, and 
TABLE VII

The effect of nebulized bronchodilator on the work of breathing in patients with emphysema and right heart failure

\begin{tabular}{|c|c|c|c|c|c|c|}
\hline \multirow[b]{3}{*}{ Subject } & \multicolumn{6}{|c|}{$\begin{array}{l}\text { Work of breathing } \\
\text { (gm. m./liter ventilation) }\end{array}$} \\
\hline & \multicolumn{2}{|c|}{ Elastic } & \multicolumn{2}{|c|}{ Viscous } & \multicolumn{2}{|c|}{ Total } \\
\hline & Before & After & Before & After & Before & After \\
\hline $\begin{array}{l}\text { F. B. } \\
\text { W. B. } \\
\text { E. H. } \\
\text { J. M. } \\
\text { L. S. } \\
\text { E. W. }\end{array}$ & $\begin{array}{l}15.0 \\
50.3 \\
88.0 \\
63.0 \\
85.0 \\
55.0\end{array}$ & $\begin{array}{l}12.5 \\
40.0 \\
70.5 \\
40.6 \\
66.0 \\
40.0\end{array}$ & $\begin{array}{r}91.0 \\
72.2 \\
130.0 \\
140.4 \\
170.2 \\
94.6\end{array}$ & $\begin{array}{l}73.8 \\
48.0 \\
95.8 \\
79.8 \\
95.0 \\
68.5\end{array}$ & $\begin{array}{r}78.7 \\
77.3 \\
165.8 \\
182.0 \\
175.7 \\
96.2\end{array}$ & $\begin{array}{r}68.8 \\
70.2 \\
137.5 \\
95.4 \\
113.3 \\
70.4\end{array}$ \\
\hline Mean & 59.4 & 44.9 & 116.4 & 76.8 & 129.3 & 92.6 \\
\hline
\end{tabular}

Mead, McIlroy, Selverstone, and Radford (15) in normal individuals after the inhalation of nebulized histamine.

In the basic work on this subject, Bayliss and Robertson (16) and Dean and Visscher (17) found an increased rigidity of the lungs with increased respiratory rate. They explained these findings by visualizing the lungs as a system with two elastances, only one of which was ventilated at rapid respiratory rates while both took part in ventilation at lower rates. Such a hypothesis also serves to explain the changes in compliance with respiratory rate in the patients reported in this study. In these patients the changes in estimated compliance at different respiratory rates are most readily explained by the effects of a nonuniformly distributed viscous resistance. A similar explanation has also been suggested by Mead, Lindgren, and Gaensler (18). When inspiration is slowed so that the viscous element is virtually eliminated, both high and low resistance areas of the lung will take part in ventilation and a high value for the compliance of the lung will be obtained. Conversely, at high respiratory rates portions of the lung with low viscous resistance will be overdistended and the compliance derived will be low. The change in compliance noted after the viscous resistance of the air passages had been reduced by the inhalation of a bronchodilator drug would further support this concept. For these reasons the term functional compliance, which is subject to variation with the respiratory rate, has been used to denote the elastic resistance offered by the lungs while breathing, in contrast to the static compliance which is independent of the resistance to air flow and represents the overall elastic properties of the lung. The latter can only be measured when sufficient time is allowed for equilibrium of volume and pressure to occur between different portions of the lung.

The results reported in this study may help to reconcile the discrepancy between the increased rigidity of emphysematous lungs described by Stead, Fry, and Ebert (19) and McIlroy and Christie (20) and the generally held concept derived from post-mortem findings of voluminous lungs which do not collapse and the early observations of Christie (21) that pulmonary emphysema is associated with loss of lung rigidity.

The data presented indicate that compliance varies with the amount of viscous resistance present, decreasing with increasing respiratory rate. Thus, despite the high values obtained for the static compliance of the lungs in chronic pulmonary emphysema, indicating loss of rigidity, the functional compliance was low while breathing at the resting respiratory rate. These results are, therefore, similar to those found by McIlroy and Christie (20) and are presumably due to the large element of viscous resistance which was present.

On the other hand such an explanation would not suffice for Stead, Fry, and Ebert's patients, for they were studied during static states, which should yield values comparable to those for the true compliance. Nevertheless, the low values for compliance which they reported might be due to the presence of fibrosis and congestion as in our second group of abnormal subjects, who had developed right heart failure. Here the static compliance of the lungs was much lower indicating that the lungs were stiffer and more difficult to distend, perhaps because of the development of fibrosis and vascular congestion. It is of interest that these patients had been dyspneic for the longest period of time. In those patients with apparently uncomplicated emphysema whose static compliance was within the normal range, loss of elasticity may have been obscured by the preponderance of fibrosis.

The data presented in this study suggest that there is a considerable amount of alveolar wall damage with loss of elasticity early in emphysema and that fibrosis and congestion may be present in 


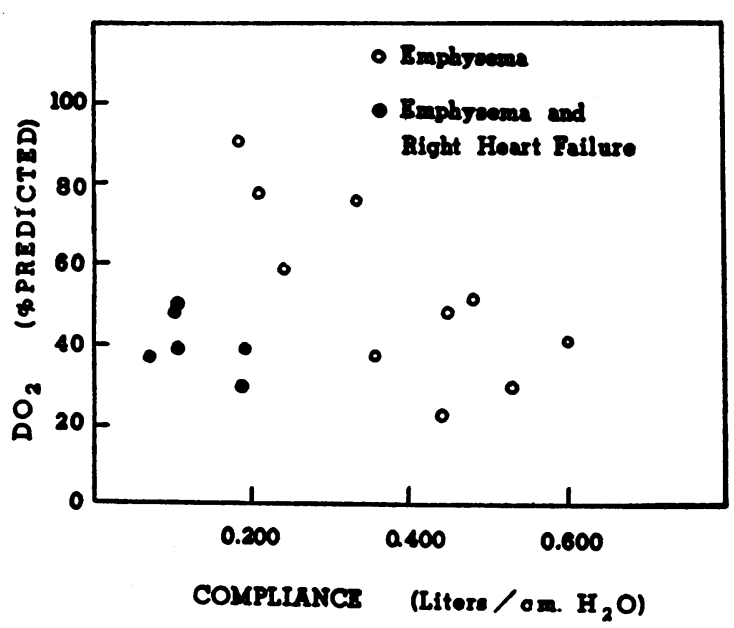

Fig. 6. The Relationship between Static Compliance and Maximal Diffusing Capacity for OXygEN, IN EMphysema aNd in EMPhysema and Right Heart Failure

the cases with right heart failure. Since the maximal diffusing capacity has been suggested as an estimate of the amount of alveolar damage and reduction of pulmonary area available for diffusion of oxygen (22), it is of interest that there was a rough relationship between the static compliance and the maximal diffusing capacity for oxygen in the emphysematous patients (Figure 6). When right heart failure was present there appeared to be a disproportionate reduction in the lung compliance.

In assessing the values reported for viscous resistance, consideration must be given to the fact that the compliance is a component of the calculation, and to the observation that compliance varies with the frequency of respiration and rate of air flow in the patients who have a high element of viscous resistance. If viscous resistance is determined from a pressure-volume loop it is also apparent that the line representative of the compliance will not be a straight line joining end expiration and end inspiration, but will be a curved line proportional to the rate of air flow. Since the pressure required to overcome the viscous resistance is equal to the difference between intrathoracic pressure and the pressure required to overcome elastic resistance, this implies that the amount of viscous resistance will be over-estimated. This is particularly true for the value for turbulent resistance since this is determined at high rates of flow. On the other hand, the value for laminar resistance is obtained at lower rates of air flow and the value for the coefficient of linear resistance is probably a good approximation. Determination of pressure-flow characteristics by interruption of air flow at the mouth would be similarly affected since the static compliance measured during the period of interruption would probably be higher than the functional compliance during that particular breath. This would serve as the explanation for our observation and that reported by Fry, Ebert, and Stead (13), that a rounded slope precedes the development of the plateau in intrathoracic pressure during interruption of air flow in emphysematous patients.

Despite these considerations the high values obtained for the co-efficients of viscous resistance suggest that there is a large element of viscous resistance, both laminar and turbulent, in the subjects with pulmonary emphysema, particularly in those who had developed right heart failure. A marked increase in work was thus required in order to overcome the viscous resistance. It is of interest that there is a rough correlation between the work required to overcome viscous resistance during normal respiration and the maximum breathing capacity (Figure 7).

The beneficial effect of a single administration of nebulized bronchodilator in the patients with chronic obstructive pulmonary emphysema is em-

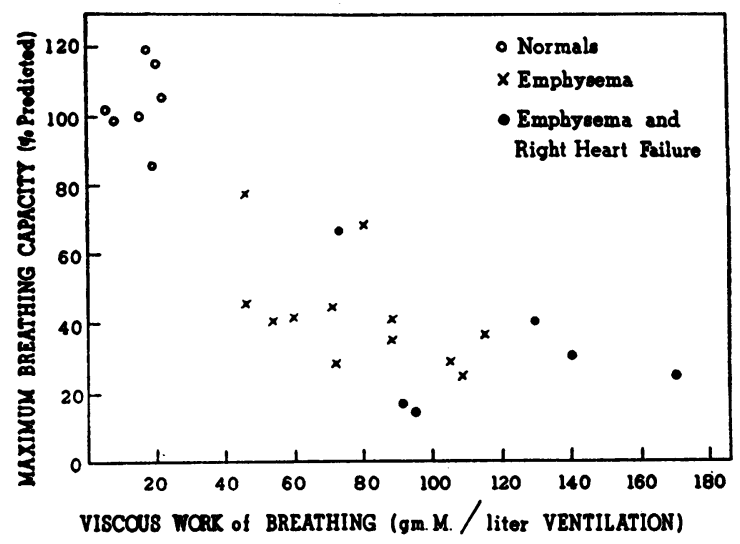

Fig. 7. The Relationship Between Work ReQUired to Overcome Viscous Resistance during Spontaneous Respiration and the Maximum Breathing Capacity in Normal Subjects, and Subjects with Emphysema, and Subjects with Emphysema and Right Heart Failure 
phasized by the marked reduction of both linear and turbulent resistance to air flow that was obtained with the resulting decrease in work of breathing due to the decreased viscous resistance and increased functional compliance.

From the data reported, it is apparent that even at the resting rate of respiration, both elastic and viscous resistances are high in chronic obstructive emphysema, particularly after the development of right heart failure. An increased amount of work is therefore required in order to overcome both of these resistances. An increased rate of respiration further increases the work required to overcome both elastic and non-elastic resistance, and the increased work of breathing must therefore limit exercise tolerance and the performance of the maximum breathing capacity.

\section{SUMMARY AND CONCLUSIONS}

The physical properties of the lungs were measured in 7 normal subjects, and 18 patients with chronic obstructive emphysema, 6 of whom had developed right heart failure.

In patients with pulmonary emphysema, the compliance of the lungs varied with the respiratory rate, the functional compliance during spontaneous breathing being lower than the normal. In the normals, functional and static compliance were approximately the same. These findings in the abnormal subjects are most readily explained by the effects of a non-uniformly distributed viscous resistance. Measurements of static compliance indicated a loss of rigidity of the lungs in pulmonary emphysema and increased rigidity in cases with associated right heart failure.

Since the compliance varied with the rate of air flow in emphysema, the viscous resistance, and particularly that resulting from turbulence, may be overestimated.

At the resting rate of respiration both elastic and viscous resistances were high in emphysema, particularly, after the development of right heart failure. Any increase in respiratory rate increased the amount of work required for respiration.

A single dose of nebulized bronchodilator diminished both viscous and elastic resistance to respiration in patients with pulmonary emphysema.

\section{ACKNOWLEDGMENTS}

The author wishes to thank Dr. R. H. Shepard and Dr. R. L. Riley for valuable advice, and Miss Beverly McNamara for her assistance.

\section{REFERENCES}

1. Otis, A. B., Fenn, W. O., and Rahn, H., Mechanics of breathing in man. J. Applied Physiol., 1950, 2, 592.

2. Baldwin, E. deF., Cournand, A., and Richards, D. W., Jr., Pulmonary insufficiency. I. Physiological classification, clinical methods of analysis, standard values in normal subjects. Medicine, 1948, 27, 243.

3. Riley, R. L., Cournand, A., and Donald, K. W., Analysis of factors affecting partial pressures of oxygen and carbon dioxide in gas and blood of lungs: Methods. J. Applied Physiol., 1951, 4, 102.

4. Riley, R. L., Shepard, R. H., Cohn, J. E., Carroll, D. G., and Armstrong, B. W., Maximal diffusing capacity of the lungs. J. Applied Physiol., 1954, 6, 573.

5. Fry, D. L., Stead, W. W., Ebert, R. V., Lubin, R. I., and Wells, H. S., The measurement of intraesophageal pressure and its relationship to intrathoracic pressure. J. Lab. \& Clin. Med., 1952, 40, 664

6. Dornhorst, A. C., and Leathart, G. L., A method of assessing the mechanical properties of the lungs and air-passages. Lancet, 1952, 2, 109.

7. Mead, J., and Whittenberger, J. L., Physical properties of human lungs measured during spontaneous respiration. J. Applied Physiol., 1953, 5, 779.

8. Cherniack, R. M., Farhi, L. E., Armstrong, B. W., and Proctor, D. F., A comparison of esophageal and intrapleural pressure in man. J. Applied Physiol., 1955, 8, 203.

9. Cherniack, R. M., and Proctor, D. F., The mechanics of breathing. A comparison of results utilizing esophageal and intrapleural pressures in man. To be published.

10. Mcllroy, M. B., Marshall, R., and Christie, R. V., The work of breathing in normal subjects. Clin. Sc., 1954, 13, 127.

11. Comroe, J. H., Forster, R. E., DuBois, A. B., Briscoe, W. A., and Carlsen, E., The Lung: Clinical Physiology and Pulmonary Function, Chicago, Year Book Publishers, 1955.

12. Otis, A. B., The work of breathing. Physiol. Rev., 1954, 34, 449.

13. Fry, D. L., Ebert, R. V., Stead, W. W., and Brown, C. C., The mechanics of pulmonary ventilation in normal subjects and in patients with emphysema. Am. J. Med., 1954, 16, 80.

14. Otis, A. B., and McKerrow, C., Possible mechanism contributing to uneven pulmonary ventilation. Federation Proc., 1954, 13, 107.

15. Mead, J., McIlroy, M. B., Selverstone, N., and Radford, E. P., Mechanical factors in the distribution 
of ventilation during short-term volume cycles. Federation Proc., 1954, 13, 98.

16. Bayliss, L. E., and Robertson, G. W., The viscoelastic properties of the lungs. Quart. J. Exper. Physiol., 1939, 29, 27.

17. Dean, R. B., and Visscher, M. B., The kinetics of lung ventilation. An evaluation of the viscous and elastic resistance to lung ventilation with particular reference to the effects of turbulence and the therapeutic use of helium. Am. J. Physiol., 1941, 134, 450.

18. Mead, J., Lindgren, I., and Gaensler, E. A., The mechanical properties of the lungs in emphysema. J. Clin. Invest., 1955, 34, 1005.
19. Stead, W. W., Fry, D. L., and Ebert, R. V., The elastic properties of the lung in normal men and in patients with chronic pulmonary emphysema. J. Lab. \& Clin. Med., 1952, 40, 674.

20. McIlroy, M. B., and Christie, R. V., The work of breathing in emphysema. Clin. Sc., 1954, 13, 147.

21. Christie, R. V., The elastic properties of the emphysematous lung and their clinical significance. $\mathrm{J}$. Clin. Invest., 1934, 13, 295.

22. Shepard, R. H., Cohn, J. E., Cohen, G., Armstrong, B. W., Carroll, D. G., Donoso, H., and Riley, R. L., The maximal diffusing capacity of the lung in chronic obstructive disease of the airways. Am. Rev. Tuberc. \& Pulm. Dis., 1955, 71, 249. 